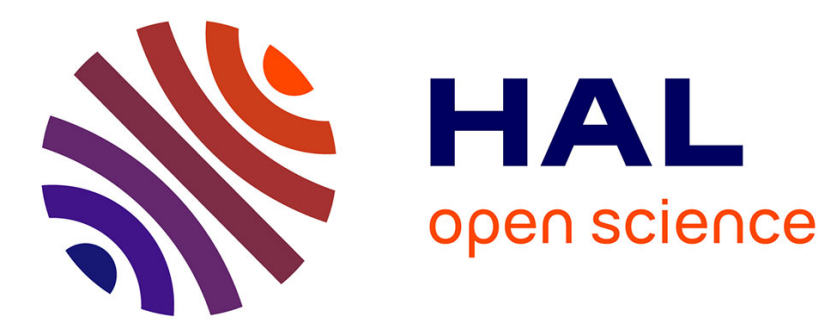

\title{
Voices from the "Heart" Understanding a Community-Engaged Festival in Vancouver's Downtown Eastside
}

Jing Li, Danièle Moore, Suzanne K. Smythe

\section{- To cite this version:}

Jing Li, Danièle Moore, Suzanne K. Smythe. Voices from the "Heart" Understanding a CommunityEngaged Festival in Vancouver's Downtown Eastside. Journal of Contemporary Ethnography, 2017, pp.1-27. 10.1177/0891241617696808 . hal-01491417

\section{HAL Id: hal-01491417 https://hal.science/hal-01491417}

Submitted on 16 Mar 2017

HAL is a multi-disciplinary open access archive for the deposit and dissemination of scientific research documents, whether they are published or not. The documents may come from teaching and research institutions in France or abroad, or from public or private research centers.
L'archive ouverte pluridisciplinaire HAL, est destinée au dépôt et à la diffusion de documents scientifiques de niveau recherche, publiés ou non, émanant des établissements d'enseignement et de recherche français ou étrangers, des laboratoires publics ou privés. 


\section{Author Queries}

Journal title: $\quad$ JCE

Article Number: $\quad 10.1177 / 0891241617696808$

Dear Author/Editor,

Greetings, and thank you for publishing with SAGE. Your article has been copyedited, and we have a few queries for you. Please respond to these queries when you submit your changes to the Production Editor.

Thank you for your time and effort.

NOTE: Please answer the queries by editing within the article: follow the AQ hyperlink below and edit the text directly. Add a "New Comment" (in the "Review" tab), if the correction cannot be done directly or for further queries.

Below, please tick the boxes to the right of the query, to indicate the query has been dealt with.

Please assist us by clarifying the following queries:

\begin{tabular}{|l|l|c|}
\hline Query No. & Author Query & $\square$ \\
\hline & $\begin{array}{l}\text { Please confirm that all author information, including names, affiliations, } \\
\text { sequence, and contact details, is correct. }\end{array}$ \\
\hline & $\begin{array}{l}\text { Please review the entire document for typographical errors, mathematical } \\
\text { errors, and any other necessary corrections; check headings, tables, and } \\
\text { figures. }\end{array}$ \\
\hline & $\begin{array}{l}\text { Please confirm you have reviewed this proof to your satisfaction and } \\
\text { understand this is your final opportunity for review prior to publication. }\end{array}$ \\
\hline & $\begin{array}{l}\text { Please confirm that the Funding and Conflict of Interest statements are } \\
\text { accurate. }\end{array}$ \\
\hline AQ 1 & $\begin{array}{l}\text { Fine 1979 is not cited in the text. Please indicate where a citation should } \\
\text { appear or allow us to delete the reference. }\end{array}$ \\
\hline AQ 2 & $\begin{array}{l}\text { Yin 2014 is not cited in the text. Please indicate where a citation should } \\
\text { appear or allow us to delete the reference. }\end{array}$ \\
\hline AQ 3 & \begin{tabular}{l} 
Please provide a short, 2- to 3-sentence bio for each author. \\
\hline
\end{tabular} \\
\hline
\end{tabular}




\title{
Voices from the "Heart": \\ Understanding a \\ Community-Engaged $\quad 10.1177108912416177696808$ Community-Engaged iournals saaenub.com/homelice Festival in Vancouver's Downtown Eastside

\section{Jing $\mathrm{Li}^{1}$, Danièle Moore ${ }^{1}$, and Suzanne Smythe ${ }^{1}$}

\begin{abstract}
This study presents findings from an ethnographic case study of a community-engaged festival held annually in Downtown Vancouver. It explores how the festival functions as a small group that contributes to the establishment of local culture and place identities in order to resist engrained stereotypes. This study also examines the ephemeral space of the festival as an interactional arena where participants co-engage in the construction of community, identity, and meaning. The study expands the discussion of community festivals as socially meaningful devices for collective action, community building, and multiliterate meaning-making in urban environments.
\end{abstract}

\section{Keywords}

small group, local culture, festival, multiliteracies

Neighborhoods are often accorded identities as "good" (e.g., middle-class, safe) or "bad" (e.g., high poverty rate, unsafe), sometimes by people who reside in these neighborhoods, but most often by those who do not. In Vancouver, the Downtown Eastside (DTES) is known as "the poorest postal code in Canada”.". Although many people in Vancouver outside the DTES associate the neighborhood with poverty and powerlessness, the tiniest ${ }^{1}$ Faculty of Education, Simon Fraser University, Burnaby, British Columbia, Canada

\section{Corresponding Author:}

Jing Li, Simon Fraser University, 8888 University Drive, Burnaby, British Columbia V5A 1S6, Canada.

Email: jla363@sfu.ca 
scratch at the surface uncovers rich stories of local residents who act collectively to contest these engrained stereotypes. For many years, the DTES community has taken collective action to affirm a common identity oriented to resisting processes of gentrification and surveillance that threaten to divide and disperse its residents. One of these actions, also our study focus, is an annual community festival: the Heart of the City Festival (HOTCF) that has taken place in the DTES of Vancouver since 2004. With multiple modes of visual and audio expressions (e.g., visual arts, dancing, music, digital stories, and poetry), Festival participants produce metaphoric and creative reflections on social realities and issues concerning themselves and their community. By doing so, they create a unique local culture that negotiates and changes inequalities that keep them disadvantaged.

Festivals are a vital aspect of the cultural and urban lives and have gained currency in multiple disciplines because of "the universality of festivity and the popularity of festival experiences" (Getz 2010, 1). A literature review of festivals in sociology and cultural anthropology highlights how such communal celebratory events have provided an analytical window for the study of their impacts on urban cities and communities (e.g., Delgado 2016; Foley and McPherson 2007; Jepson and Clarke 2016; Moscardo 2007; Reid 2007), community identity construction and cohesion (Derrett 2003; Elias-Vavotsis 2006), the symbolic relationships between festivals, place, and branding (McClinchey 2008; Reid 2006; Wynn 2015), and urban development and renewal (Che 2008; Hughes 1999). Despite the multitude of festival studies, theory still lags behind practice with regard to urban community practice and celebratory events (Delgado 2016). As Delgado (2016) points out, ordinary residents, not only event planners or community organizers, are responsible for most community celebratory events. However, the ongoing discussions on festivals leave little room for understanding how "ordinary" individuals, especially disadvantaged groups in community settings, experience festivals and how they make sense of those experiences. Getz's (2010) analysis of the nature and scope of festival studies has suggested that much research has been conducted on the economic, operational, and motivational aspects of festivals, while the analytic focus on actual experiences and meanings attached to them is absent.

Sociologists in recent years have begun to apply a local/group sociological approach to festival studies (see Delgado 2016; Wynn 2015, for further discussion). Gary Alan Fine $(2012,117,116)$ describes festivals as "focused microgatherings" and "the archetypal form of wispy communities." $\mathrm{He}$ argues that wispy communities/small groups are the basic building blocks of ${ }^{1}$ Faculty of Education, Simon Fraser University, Burnaby, British Columbia, Canada

\section{Corresponding Author:}

Jing Li, Simon Fraser University, 8888 University Drive, Burnaby, British Columbia V5A 1S6, Canada.

Email: jla363@sfu.ca 
society and play a pivotal role in organizing social life and developing local cultures and identities. In Music/City: American festivals and placemaking in Austin, Nashville, and Newport, Wynn $(2015,9)$ conceptualizes festivals as "an occasional public" wherein local actions and greater social forces come together for bounded periods to engage in cultural work. He accordingly suggests a microstructural lens be applied to study urban festivals. Delgado (2016) also recognizes the value of the meso-level analysis in enhancing the knowledge about multiple functions of community celebratory events. Attending to the often-neglected and unexplored microdynamics of local fields of action, the group sociological approach provides a useful explanatory framework to understand how our social worlds are locally organized in group settings, which sheds light on our understanding of community festivals in new ways.

Combining Fine's (2010, 2012) local/group sociological approach and Borer's (2006b) urban culturalist perspective, the current study explores the roles of the HOTC Festival in the lives of community residents and construction of community and identity. We wish to explore the Festival as a context for the formation of place identities and local culture that counters an unwanted Othering identity formed by those outside the community. This ethnographic study also involves exploring the ephemeral space of festivals as a local interactional arena where participants co-engage in meaning-making and place-making. Specifically, the study addresses three related questions: (1) How does the Festival foster participants' connections to the community and to the (re)construction of community identity? (2) What are the effects of local culture created within the Festival on community building, meaning-making, and place-making? and (3) What are the affordances of the theory of group action and culture (Fine 2010, 2012) and urban culturalist perspective (Borer 2006b) for conceptualizing the roles of the Festival in local culture development and group-culture-place relationships?

\section{Theoretical Framework}

The theoretical perspectives from which we approach the research questions are the group action and culture theory (Fine 2010, 2012) and urban culturalist framework (Borer 2006b). In his-Tiny Publics, Fine develops a local sociological framework for describing and analyzing small groups and the establishment of local/group culture, which he refers to as "idioculture" $(2012,3)$. A local sociology holds that small groups, which Fine thinks of as local interactional arenas, are the microfoundation of social structure. The group is society writ small and of paramount significance as an explanatory 
tool in recognizing local diversity and local effects, argues Fine. Within the boundaries of group settings, local culture, which he refers to as "idioculture" $(2012,3)$ - a unique set of meanings, knowledge, behaviors, and customs - is produced and performed as the outcomes of participant interactions. Discussing his view of culture, Fine asserts that culture is locally produced in microcommunities and embedded within interaction. He $(2012,35)$ writes, "We must conceptualize culture in light of those behavioral domains in which it is embedded. Societies are said to "have" culture, but culture is performed and displayed to particular audience (even through media productions, created by groups that have extended audiences)"-(Fine 2012, 35). The interpretation of culture as a message embedded in interaction and created locally for audiences provides new analytical insights into urban festivals as local contexts for culture formation, learning, and place/meaning-making.

Wynn $(2015,9)$ has stated that festivals are occasions and moments of collaborative meaning-making wherein "creative activities of individuals and the constraining and empowering forces of social structures" occur simultaneously. Fine $(2012,117)$ goes so far as to define festivals as "focused microgatherings" (117) -in which social ties are developed and identities generated. He contends that occasions and gatherings are typical forms of small groups where individuals with common interests and the shared past congregate and interact with each other to create meaning and order. Festivals' inherent nature as small communities which encourage local individuals' actions and forge local culture accordingly returns us to a meso-level analysis of such group contexts. The small-group perspective allows us to situate individual agency and group dynamics within festival contexts to address "many of the elements associated with celebratory events and why they can transform communities" (Delgado 2016, 6).

To address the multiple roles of the HOTC Festival in place-making and local culture development, we turn to the "urban culturalist perspective" (Borer's 2006b) to explore the connections between culture and place. This critical model comprises six distinct but interrelated domains of research: (1) images and representations of the city; (2) urban community and civic culture; (3) place-based myth, narratives, and collective memories; (4) sentiment and meaning of and for places; (5) urban identities and lifestyles; and (6) interactive places and practices. The urban culturalist perspective is used in this study particularly to analyze images/representations, civic culture, and narratives/collective memories. It helps us position the present study within culture-place relationships to understand how Festival participants make sense of the meanings of place through Festival participation, and how they address the issues that they see as a threat to their community. By combining the small group theory and urban culturalist 
perspective, we hope to discern and recognize the connections among group, culture, and place in the Festival context in order to understand the festivat Festival functions as a site of identity formation, community building and collective action among community residents.

We also draw upon the concepts of multiliteracies, or multimodal literacies, ${ }^{1}$ to refer to variability and multiple modes (language, visual, spatial, and digital) of meaning-making (Albers and Harste 2007; Kress 2000; New London Group 1996). Multiliteracies, according to Sanders and Albers (2010), incorporate the arts, literacies, and new media. They signal multiple communication channels, hybrid text forms, new social relations, and the increasing salience of linguistic and cultural diversity (Cope and Kalantzis 2000; Hull and Schultz 2001; New London Group 1996). Acknowledging that any single mode is only partial (New London Group 1996), multiliteracies approaches to literacy studies reflect a shift in understanding literacy as a singular form of verbal or written expression (reading and writing) to a visual expression across modes (multiliteracies). In the Festival setting, the concept brings attention to how meaning making is distributed across visual and auditory modes and movements (literacies beyond written texts), and to the "complex relationships among and between modes in constructed texts” (Albers and Harste 2007, 11).

\section{The Downtown Eastside Context and Heart of the City Festival}

Located just a few blocks away from the city's affluent business center, the DTES is Vancouver's oldest neighborhood. As the historic heart of the city from where Vancouver has grown and developed, the DTES neighborhood is culturally and ethnically diverse. The DTES, like Vancouver itself, is located on the unceded territories of the Coast Salish Musqueam, Squamish, and Tsleil-Wauthuth First Nations. Indigenous people from all over Canada call the DTES their home. Chinese and Japanese communities and new immigrants from Europe were among its earliest settlers, arriving in the 1870s as economic migrants and temporary foreign workers in the village nicknamed Gastown. The neighborhood was also once home to a thriving African Canadian community. Now it is still home to Chinese opera and New Year Parades, Japanese Taiko drumming, Aboriginal ceremony and anticolonial activism, and Ukrainian New Year Celebrations.

Despite its cultural richness, the DTES is often recognized as one of the most impoverished neighborhoods in Canada. It was estimated that "18,477 people lived in the neighborhood in 2011. More than half of the residents are poor, dependent on Income Assistance support, pensions, charitable and 
social services” (DTES Plan, City of Vancouver 2015, 18-19) and relying upon the relatively affordable but quickly gentrifying supply of run-down single-room occupancy hotels. People here disproportionately struggle with homelessness, poverty, mental illness, addiction, and exacerbated by unaffordable and insecure housing. Ungenerous journalistic and media representations have framed the area as "Canada's poorest neighbourhood" (Hopper 2014) and $_{2}$ "the poorest of poor neighbourhoods" (Brethour 2009), and so forth. These descriptions used by both international and local media reinforce a unidimensional view of the community as a rough environment. Ironically, as Robinson $(2012,16)$ observes, "the DTES is at once within the city and apart from it.”

It is in the midst of these harsh media representations that the HOTC Festival was launched in 2004. The HOTC Festivat It is an annual two-week community event featuring arts performances, music, dancing, comedy, poetry, craftwork, and other cultural and heritage activities created by and for community members and allies that have close ties to the community. Unlike most festivals that are alliances between arts and commerce, the Festival is mostly free, remaining accessible to the public in an area where many people are unable to pay even token entry fee. The Festival originally developed out of a successful local arts production in celebration of the centennial of the historic Carnegie building that is home to the Carnegie Community Center: In the Heart of a City: The Downtown Eastside Community Play. the HOTC Festival is currently coproduced by Vancouver Moving Theatre ${ }^{2}$ (VMT) with the Carnegie Community Centre, the Association of United Ukrainian Canadians, and more than one hundred community partners that include local First Nations, Chinese, and Japanese cultural associations, local history and cultural societies, artists, and writers.

\section{Data Collection and Participants}

Data in this paper mostly come from fieldwork conducted over a sixteen-month period from 2013 to 2015 (The Festival falls between the last week of October and the first week of November each year). The project started in 2013 as a Languages, Cultures and Literacies course assignment that asked education graduate students to explore ethnographic research approaches while attending the Festival, drawing upon field journaling and photo documentation. As part of the coursework, Author $1^{3}$ observed Festival events and mingled with Festival participants, and then obtained in $2014 \mathrm{a}$ more comprehensive ethical protocol to discuss with participants about their experiences of the Festival. Based on these experiences and intense observation activities, fifteen semi-structured interviews were conducted in 
2014 with an interview protocol that addressed the questions guiding the study. To make sure that we obtained a fuller picture and establish trustworthiness, after the 2014 Festival, further interviews were conducted with participants across a wide range of roles and cultural backgrounds, including community residents, actors/performers, organizers, audiences, volunteers, sponsors, and working staff. A total of twenty-five interviews have been made. Interview questions generally focused on participants' roles in, experiences with, and perceptions of the Festival. Questions with Festival producers were mainly about the production process and logistics. Twenty Festival events/performances were chosen to be attended from those recommended on the Festival website and those that were closely relevant to the annual theme of the Festival. A research journal was kept to document reflections on particular events and interactions. AHA Media (the Festival's media partner) uploaded all major events on YouTube and thus provided artifacts of social media on the Festival (e.g., video, photos, and blogs), which offered us more flexibility to review a range of Festival productions and media texts generated during the Festival.

Multiple sources of data were collected, including interview transcripts, written records of informal conversations, reflexive postobservation fieldnotes, visual artifacts, and media texts (e.g., photos and video clips). The Festival website, program guides, comment books, and other related documents were also referred to.

Using pseudonyms to protect study participants' identities is the common practice in research. However, we followed the advice and examples of Borer (2010) and Wynn (2015) of keeping places' and participants' real names and consulted with community members regarding their preferences when they signed the consent form. Except those who were quoted from secondary sources (e.g., newspapers, Festival comment books) or from whom no permission was obtained, we present in this article the real names of the interviewees to respect their preference to include their genuine voice. By making the names of places and people known without causing any significant harm to the participants, we hope to preserve those particular identities and histories that make them unique (Borer 2010,99) and offer "the public voice and recognition" (p. 99)-that supports the Festival goal to share experiences and concerns with others as part of the work of public education about colonialism, and also the creativity and agency of the community that is so often maligned.

\section{Negotiating Access to the Site}


Preliminary negotiation to carry out interviews was made through casual conversations with Festival participants when we attended the Festival in 2013, developing relationship with some local residents who had differing levels of involvement in the Festival. As the fieldwork further proceeded, the initial contacts have led to closer relationships with some long-time participants/residents. Occasionally, the first author was invited by local residents to join their dress rehearsals and pre/post-festival-Festival workshops, which allowed for a unique insider perspective to observe and record participants' collaboration and interaction at and off the Festival. Throughout the three-year fieldwork, the researcher appreciated these generous offers of friendship and insight into the values and cultures of the Festival and sought to reciprocate by volunteering in the community center in return for residents' generosity and hospitality. Gaining access, as Yin (2011) notes, is a process, not a one-time event. It was an essential process in this study to maintain access all along, establishing new relationships at each Festival while nurturing the relationships already made in the previous year(s) based on mutual respect and trust with community members.

\section{Conducting Reciprocal and Collaborative Research}

As argued by Lather (1986, 73), the methodological task of any empowering research is to proceed in a reciprocal, dialogic manner; the researcher's role should be of a "catalyst who works with local participants to understand and solve local problems.” From the outset, we included participants' voices to promote collaborative learning and research design. During our initial contacts and interviews with Festival participants, we assured them that their name would be replaced by a pseudonym and other personal information not be disclosed in public dissemination. However, many of them expressed a preference to have their real names included so their genuine voice could be heard. Some participants also pointed out that the consent form we first used with them was jargon-laden and may cause difficulty in understanding for those community residents who lacked adequate literacy skills. Adopting these suggestions, we co-developed a revised consent form in response to the participants, in which they were offered a chance to choose whether they wanted to keep their real names in the project. At the later stage of the fieldwork, an open discussion was facilitated in the community center to share research results with local residents and Festival participants. In doing so, we were able to share the preliminary findings of the fieldwork with community members and listen to their feedback and interpretations. With these mutual feedback processes, we sought to establish a shared trust with 
participants and create a space for better research practices and protocols (Pidgeon and Cox 2002) that are more relevant to the community and its residents.

\section{Making Sense of the Community through Collective Memories/Narratives}

The DTES neighborhood is the ancestral lands of Coast Salish peoples, who were forcibly removed from the area during industrialization. The First Nations still live and work on the shores of the Pacific and in the community, and indeed have never ceded the territory that has been claimed as the jurisdiction of the City of Vancouver and of the Provincial and Federal Governments. The community is also home to Japanese Canadians, Ukrainian Canadians, and other settlers. During WWII, Japanese Canadians in the neighborhood were removed from their homes, their property confiscated, and their communities moved to internment camps across Canada. Some of the community returned, but the area around the Vancouver Japanese Language School \& Japanese Hall and Powell Street has become more of a historic site today, known as "Japantown.." Now the second- and third-generation Japanese Canadians and Ukrainian Canadians who live in other areas of the city and province return to the neighborhood every year for community celebratory events, such as the HOTC Festival. Many participate in traditional cultural and heritage activities and, as some of the Japanese Canadians whom we met at the Festival said, "learn about the history of Powell Street . . . and our own cultural and historical backgrounds.” An example of the entangled histories of Indigenous and Japanese communities is the multicultural performance Against the Current (2015), a remarkable cultural/artistic experience at the Festival that brought together the Japanese Canadian community and Salish community in the DTES, featuring Japanese Taiko drumming, Salish songs, and storytelling to celebrate the shared role of salmon in Salish and Japanese history, culture, mythology, and economy. The following fieldnote is drawn from the performance.

(8:30 p.m., Friday) I arrived late at the Vancouver Japanese Language School \& Japanese Hall where the show was held and missed the first part. Had to stand at the back of the hall to avoid disrupting the show L. It was quiet in the hall except the soothing voices from two storytellers, an elderly Japanese lady and a First Nation woman telling of the salmon swimming upstream. . . . The drumming took over and the intensity of the drumming beats steadily grew. . . . The First Nation woman then began to tell a story of her sharing a meal with a group of Japanese Canadian fishermen while moored with her father on Galiano Island. . . . Throughout the performance, snippets of memories of early 
Japanese immigrants and Indigenous peoples enduring the hardships were beautifully woven into multi-textured fabric of song, dance, drumming and spoken word. The salmon and its lifecycle were a unifying theme and a metaphor for the lifecycle and journey home for Japanese-Canadians and First Nations. The Indigenous and Japanese drummers, singers, and dancers, both old and young, overwhelmed the stage with their energetic and passionate presence as they revealed shared experience of swimming against the current. At the end of the show, over 25 DTES community participants carried a three-foot long papier maché salmon prop walking through the audience. . . . So for an hour and a half, I stood there as one of the audience at this performance and found that my pulses were constantly on with the Taiko drumming and Salish music. Perhaps others felt the same sensation that engaged me so intensely. When it was over, the full room of the audience erupted in applause, rising in a standing ovation. (Author 1, fieldnotes, November 6, 2015)

Conversing with some attendees and actors after the performance, we noticed that many were long-time residents of the DTES, or once lived there. It was not hard to see that witnessing or participating in the performance offered them a window into shared memories that bound individuals and groups together. A Japanese Canadian elder said, "We don't live there anymore but we are coming to have our festival, commemorate our lives there but at the same time remembering that there are people living there and that they must be brought into our community." Grace, one of the storytellers in the performance who had experienced the forced removal of Japanese Canadians during WWII, talked later in an interview about how the shared history of Japanese Canadians and Aboriginal people fighting against injustices helped her better engage with her role as the storyteller.

Because I was quite, very much aware of the WWII Holocaust history and I also
knew partially about the Aboriginal, the treatment of the Aboriginal. So I know
that other people have suffered much more than we did. . . . So when I look at our
history and I look at the larger community histories, I realized that we really have
something common to share. . . . After we had a couple of rehearsals, even with
the rehearsal, I wasn't really getting into it as I should. . . . So finally when it was
getting close to the time, I was starting to really focused and I read it at home and
I really got into the theme of against the current, that Aboriginal people, Japanese
people, you know, who were all working against the current, and the whole idea
of using the salmon. Fighting against the current, they go to multiply and to lay
their eggs. You know, all those things became very relevant to me and I really
started to appreciate those who wrote those words. (Transcripts, November 26 ,
2015)

Grace was one of those actors and onlookers for whom the performance evoked past memories. "Against the Current has given me an opportunity to 
go back into my memories and look at our history as a First Nations family on this coast and growing up as fishermen," said the Coast Salish storyteller quoted in the performance brochure $(2015,10)$, "Being part of this project has let me look back once again in awe and amazement at a way of life that's almost disappeared in my lifetime. ... Memories of family and teachings on how to be and to live in this world, feeling connected to may past and my family again." Coming from a long line of fishermen, the storyteller wove her own stories into the performance. The script for her was not only a play script written for the performance, but a real life script as well. "The stories that I share are all real from a different time and era," she wrote in the performance brochure, "our way of life that we all knew so well is disappearing, going the way of the salmon . . . just lost" $(2015,11)$. Here, memoires of what has been and what was have become evident in reproducing and retelling the story. In a sense, Against the Current became moments of memory-retrieving time in which participants/actors were invited to walk in the world of their ancestors, reexperiencing the rich history that has shaped the community, but often been forgotten or gone unrecognized.

Bread \& Salt (2013), an annual HOTC Festival event, is another example of the memory-retrieving and place-making role of the Festival. Inspired by stories and memoires from the Ukrainian community in the DTES, the performance created a Ukrainian Canadian story woven from personal and collective memories. Professional and community actors interwove oral history of Ukrainian Canadians with multimodal expressions of live theatre, music, dance, and projected images to pay a tribute to the East End's historic Ukrainian community. The story took attendees on a journey of discovery. Shared memories and narratives of struggle and solidarity resonated, connecting audiences not only to their cultural roots but also contemporary experiences of place. The following excerpts well illustrated this point:

As a 4th-generation Jewish immigrant to Canada, whose great Grandfather helped to build the 1st Synagogue in Bytown, it was fascinating for me and quite touching to discover Vancouver's first synagogue, just down the road from the Ukrainian Hall. As so many Jews came from Ukraine and my own ancestors came from Poland/Russia, I felt a connection with this history and community I was discovering. (Downtown Eastside Heart of the City Festival Comment Book 2013)

Collective memory "connects people in the present to the facts of yesterday and how those facts were ascertained and currently received" (Borer 2006b, 186). At the Festival, actors and attendees hear in such performances as Against the Current and Bread \& Salt echoes of the many people who have arrived and lived in this community as survivors of all forms of injustice, of 
families broken up by the residential school system, internment camps, and contemporary approaches to social welfare that make families and children vulnerable to homelessness and addiction. They also hear stories of resilience and strength: immigrants from different cultural backgrounds and Aboriginal people who fought hard "against the current" and contribute to Vancouver's prosperity. S. Elizabeth Bird (2002, 526) contends that "local narratives are less about 'history' and more about how people construct their sense of place and cultural identity." At the Festival, these shared, retrospective narratives articulated through the multimodal forms of poems, personal memories, lived stories, songs, dances, projected images, and historical chronologies serve as common reference points for Festival participants to make sense of their own cultural identities and connections to the place.

Research on myths, narratives, and collective memory from the urban culturalist lens holds that "social, public, collective memories are "stored and transmitted' in and through places” (Borer 2006b, 186). Eviatar Zerubavel $(1996,292)$ reminds us that "(t)he preservation of social memories need not depend on either oral or written transmission. After all, material culture plays a very similar role in helping us retain them." In the case of the Festival, we argue that festival culture, what Wynn $(2015,228)$ refers to as "liquid culture, ${ }^{4}$ is also entangled with the materialities of place and things, and with the work of memory and place-making. In reproducing and retrieving collective memories/narratives, the Festival took on the dual role of a "mnemonic device" (Borer 2006a, 210) and knowledge-keeper, reminding people of the intertwined cultural and social histories that makes the DTES community unique and complex, while keeping these narratives/memories alive and sharing them with the next generation and with their neighbors in broader communities.

\section{Creating an Inclusive Civic Culture/Community}

Unlike those festivals that are founded by municipal or other government officials or created by professional arts groups, one special characteristic of the HOTC Festival is that it is largely community initiated, community led, and community engaged in content and production. The executive director of the Festival, Terry Hunter, said that "there is a strong sense of ownership from the community around the Festival. It's something people look forward to every year." He added, "Last year we had over a thousand residents participating in the festival as performers or presenters or artists" (transcripts, August 3rd, 2015). 24 Hours, a local newspaper, thus describes the Festival in one of its 2015 news report: "DTES residents tell story through acting. . . . 
It might sound like professional actors tensely rehearsing —instead it's DTES residents-turned actors weaving together a narrative about homelessness" (as cited in the Downtown Eastside Heart of the City Festival Comment Book 2015). It was hard to ignore a strong sense of community engagement during the encounters and interviews with Festival participants. Adrienne, a long-time community resident, has been consistently and actively involved in the Festival since it first started in 2004:

I have been in the audience, a performer as well as helping to organize events like the Learning Centre events and my own digital storytelling shows. . . . Jimmy and I wrote a play together called "who stole the spirit of Carnegie" which was first performed at the festival in 2014 . . the actors were all Carnegie (Community Centre) regulars who were great to work with. . . . Having it (the festival) in the rainiest part of the year makes it so downtown eastside for me. Nobody else puts on a festival at that time of year. (personal communication, August 19, 2016)

"So I have been continuing on with my long involvement with the Heart of the City Festival," wrote Adrienne in an email exchange after the 2016 Festival, saying that she presented another digital story called A Year in the Learning Centre (Personal communication, December 1, 2016). Having attended the Festival for three consecutive years, we witnessed individual active participation from local residents such as Adrienne and observed cross-cultural performances that intertwined culture, history, and place-making, such as Against the Current (2015) and All Our Father's Relations: Stories of Shared Chinese and First Nations Heritage (2016). Community members' collective engagement and shared participation manifested themselves in the process of working on a variety of Festival productions. In Against the Current, large papier maché salmons were members of the cast; more than twenty community residents were invited to carry the salmon during the performance. And many residents were involved in creating the big salmons before the performance. Over a period of three months before the 2015 Festival, project staff organized workshops in different venues in the DTES community and invited local residents, adults and children, to create the papier maché salmon. Some workshops involved making salmon molds, others focused on papier maché-ing those molds and painting the fish. To those who were involved, the experience of making the salmon was also a practice of remembering and renewing the central place of the Salmon in Canadian west coast ecology economy, story and culture. Speaking of community collaboration, John Endo Greenaway, the artistic director and co-writer of the performance, remarked: 
So many of these shows come out of cultural groups brainstorming about something that can be done which speaks to their experience and the neighbourhood. .. . It wasn't me sitting there thinking of the story and writing it. It really was a collaborative process. It took several years towards its completion. It (the project) developed very organically. . . . Because there was no budget for a big rehearsal, you know, very low budget, and it depended on the good will of a lot of people. (Transcripts, April 19, 2016)

Like Adrienne and those who work together on various Festival events, community members from diverse cultural and age groups in the DTESfrom street-involved youth, First Nation elders, and volunteers to community artists and activists - have engaged in the preparation and production of Festival to varying degrees throughout the year towards the yearly show. The creation of the Festival can be seen as the experience of ordinary community residents' collaboration and engagement, providing a place for involvement, pulling individuals, both within the community and outside, into shared participation and place/meaning-making. Indeed, the very acts of addressing the threats of gentrification and displacement are powerful place-making practices. Fine (2012) thinks of the small group as an interactional arena where participants engage themselves and collaboration emerges. Small groups, in most cases, "serve as the gravitational centers of civic life, drawing individuals into participation not only through compelling ideas but through material resources" (130). This statement well suits the Festival case in that it is an action space that engages DTES residents to collectively challenge mainstream media discourses and actual policies that construct the DTES community as the "down-and-out" and entrench practices of gentrification, welfare, and housing that further marginalize low-income members.

Furthermore, participants expressed that engaging in these common activities offered them an opportunity to create, experiment, and meet new people. They expressed their joy, excitement, and a feeling of satisfaction from being a part of the project. "I had tremendous fun at the HOTCF," one Festival participant said affectively, "and I feel and believe it truly reflects our community and I think it's a lot more meaningful and gratifying when one is involved in some aspect of the Festival, whatever that maybe”. Apart from personal satisfaction, the process of collaborative action also brought about a local "energy." Eyoalha Baker, the artist who created the poster mural "Wall of Joy" on the side wall of a hotel in the neighborhood and presented this work at the 2015 Festival, mentioned how the shared energy helped forge an open and welcoming atmosphere.

It (the mural) really belongs to everyone. . . . A lot of people would come down to help me out (when I installed it on the wall). And they were so proud of 
this. . . . It brought so many people together to create this thing. You made it part of their experiences too. So it's really an interactive thing, this mural. . . . I just fell in love with the neighbourhood, and people, and their openness. . . . I just felt so supported, like they really got the energy. They could really feel the energy. (personal communication, November 1, 2015)

Her feeling was echoed by another Festival visitor:

I appreciated the festival, not only for its events but also for the warm atmosphere. From the outset, I felt welcomed and included. . . . In addition to good entertainment, I also learnt much about the residents, their issues and their area. I felt that I had joined a very human group whose wit, intelligence and humor contributed greatly to my pleasure attending the festival. (Downtown Eastside Heart of the City Festival Comment Book 2014)

What characterizes a city with a strong community is the respect and recognition afforded to its members, regardless of their personal, social, and economic statuses or ethnic and cultural backgrounds. Borer (2010) argues that a vibrant civic culture is built around the variety and depth of social interactions and common activities from diverse persons across races, classes, and ages. In a similar vein, Monti $(1999,104)$ states that "civic culture makes it possible for different groups to claim the same piece of land as their own and to become part of a more inclusive community.” In Fine's local sociology, shared participation is an important feature that characterizes a group. But so too, in the Festival case, should it be recognized as contributing to producing an inclusive civic culture or community. In the course of shared participation and collaborative engagement, new relationships of respect and reciprocity have been formed, strong ties between local communities established, and richer understandings of the community's diversified cultural tradition realized. On the other hand, local residents work with each other at the Festival to contest injustices as "members of different populations with different ideas, interests, and intentions to coexist in the same geographic and social territory" (Borer 2010, 102).

\section{Accentuating a Common Community Identity}

Within the urban culturalist perspective, how place is made in the image and symbolic representation of the place is also of our interest. In this section, we examine media texts produced at the Festival and analyze such features as the layout of visual images and their modes of expression. We are interested how linguistic and semiotic resources are selected and combined at the Festival to address its hoped-for audiences and create a space for dialogue between the 
DTES and broader communities. It is this aspect of symbolic representations that we now turn to.

\section{The Symbolic Image}

At the Festival, visual representations (e.g., photos, paintings, and posters) are strategically used as supplements to local narratives and form a collective identity of the DTES community. An example is the Festival symbol (Figure 1), a phoenix that is associated with regeneration and rebirth, designed by the DTES artist Diane Wood. An excerpt from In the Heart of the City: The Downtown Eastside Community Play in 2003 beautifully elaborated the spirit of the phoenix and explained why it was chosen to represent the community identity:

Leanne: A phoenix is the most beautiful bird in the world. It lives forever. Whenever people chase it, to steal its glorious feathers, the phoenix flies to a distant land to sing in peace. When its wings grow heavy with age and death approaches, the phoenix builds itself a nest of sweet scented wigs. . . . There it sits on the nest and waits for the sun's rays to ignite into flame. Out of the flames emerges a beautiful young phoenix. Out of yesterday's tragedy, the phoenix will always return. (Festival Program Guide 2014, 40)

The visual representation of the phoenix signifier evokes a symbolic sense of renewal and becoming and facilitates a reclamation of identity-making. The legendary bird represents a life cycle that has no end, a perpetually renewing resource, just as the community and people living inside, an enduring place with a durable people. We can just say that this phoenix symbol reflects the desire and imagination of the DTES people. It also expresses the hope and longing of community members for something better, even for those experiencing displacement as a result of the rapid gentrification and high housing prices in the city. 


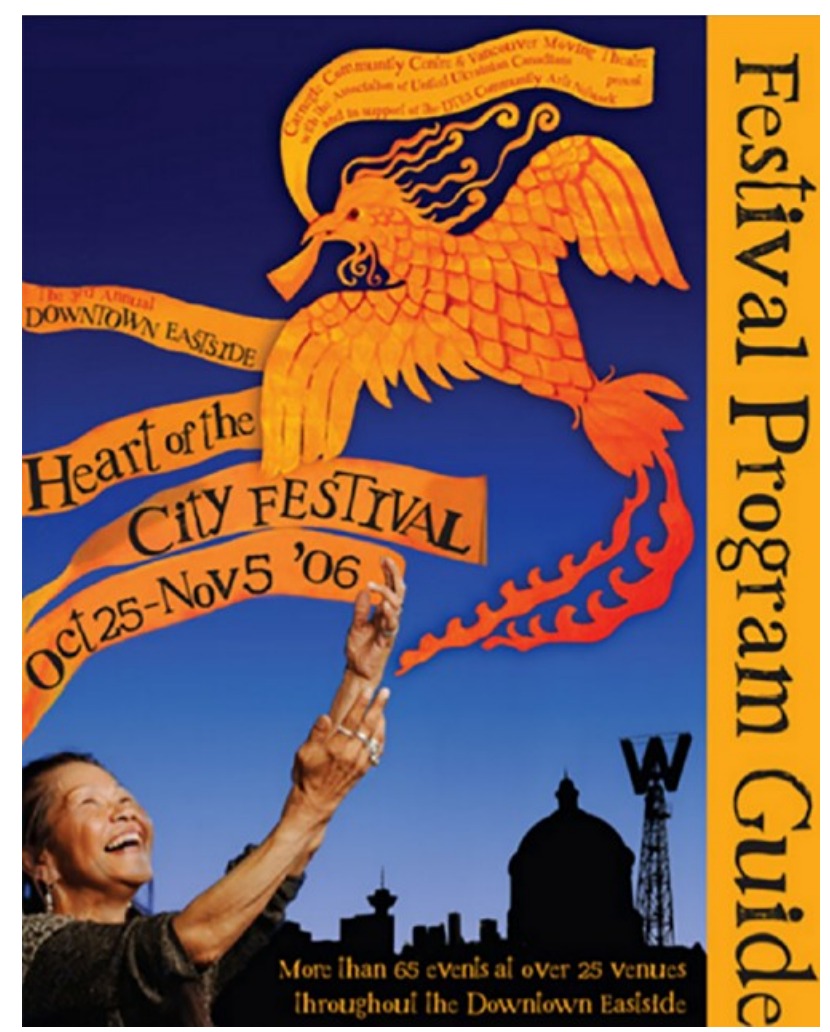

Figure 1. The phoenix illustration.

Source: Downtown Heart of the City Festival Program Guide, 2006.

\section{Community Art Projects}

Community art projects, too, were used as a tool to refute "a deficit-focused public narrative of the DTES” (Szöke 2015, 10) and exhibited the cultural diversity of the DTES. The photo of the mural Through the Eyes of Raven (Figure 2) was taken during a fieldtrip at the 2013 Festival. The mural was painted on the side of a hotel wall in the neighborhood by local artists Richard Tetrault and a team including Haisla Collins, Sharifa Marsden, Richard Shorty, and Jerry Whitehead. The first and third authors had a conversation with Jerry Whitehead about the theme of the mural in the First Nations artist studio in 2013. The mural depicts relations among Aboriginal 
people, coastal ecosystems, and colonialism, and also demonstrates the strength of their ancestry, as well as contemporary urban Aboriginal events.

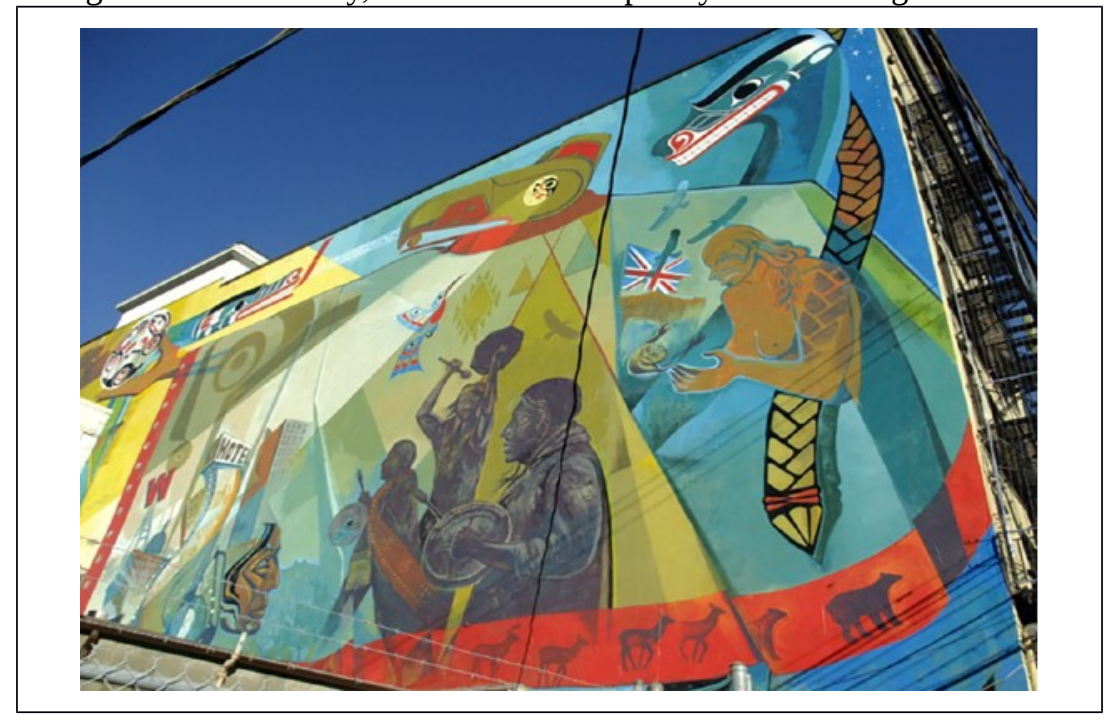

Figure 2. Through the Eyes of Raven.

In 2016, Richard Tetrault had his new work, a mural banner, The Gathering (Figure 3), presented at the Festival opening ceremony. The Gathering featured the extraordinary artists, activists, and people past and present in the DTES community. A Ukrainian folk performer, First Nations artists, an African Canadian/Cherokee singer, a Japanese Taiko drummer, a Latin-American guitarist, and a Chinese Pipa player all found space in Tetrault's latest work. With this new artwork, the artist tried to assert a positive identity of the DTES through visual arts. "Not that I don't know the negative side. . . . But if they think that's all there is to the Downtown Eastside, they're missing the boat," remarked the artist quoted in the Georgia Straight, a local newspaper (Smith 2016), “only when you go into the Downtown Eastside and don't drive through it do you realize the complexity and mutual support there is. And that's what the Festival is: accentuating the positive." Symbolic images or representations of a place can be used to create common reference points for visitors to understand that place and allow a space for dialogue between groups in the city (Borer 2006b). Cultural representations are all socioculturally situated and embedded. What we observed at the Festival is that DTESiders create symbolic representations to express their cultural and artistic richness and lived stories that shape their community. In these representations, community members add 
with their individual/collective memories and dreams to the Festival's ongoing making of the neighborhood's identity. This is well reflected in the words of an interviewee:

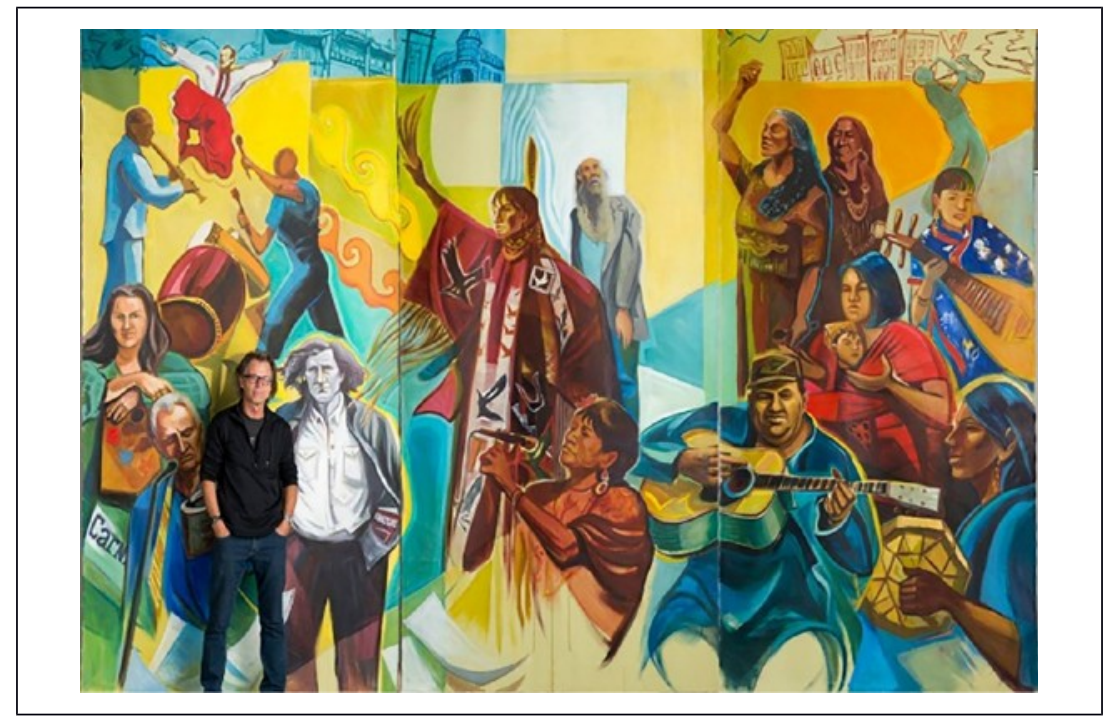

Figure 3. The Gathering.

Source: The Georgia Straight, October 19, 2016.

It (the Festival) shows to people this is not just a dead zone down here. It shows there are artists here and there is a real sense of community, people helping each other; people coming together for this Festival; people opening their doors at different venues and allowing people to come in. (Transcripts, October 28, 2014)

\section{Photographs}

In addition to public art projects, harnessing photographs also plays an essential role in countering the negative media portrait. The Carnegie Jazz band (Figure 4), taken from the 2014 Festival program guide, is a good example. The photo shows different artists who represent ethnic diversity in the community. They are depicted in close shot rather than from a distance, indicating they are socially close to any one viewer who is looking at the photo. The angle from which the photo was arranged is at the eye level, offering a sense of equality and intimacy with the viewer. Posing with their musical instruments communicates vitality and talent. This photo, among others shot in a similar manner, symbolically exudes a sense of energy and warmth. Indeed, visual images have a special role to play in identity formation and in the 
communication of ideas because they "convey layered and concretized, personalized messages, connotations and metaphors and to arouse strong feelings" (Hamilton 2012, 48). Terry Hunter emphasized the importance of visual images in properly representing the DTES and its residents:

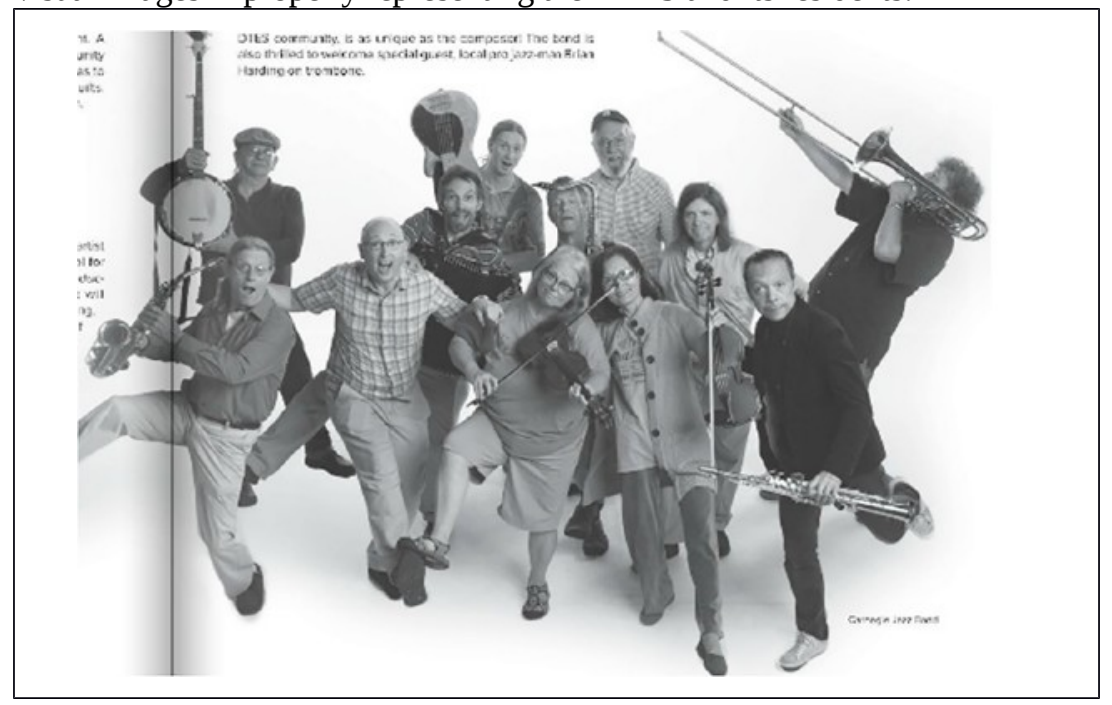

Figure 4. Carnegie Jazz Band. Source: Festival Program Guide, 2014.

So the visual component of the festival is a very, very important aspect of the work we do. ... I thought it's very important that people in the community look really good and that is one color. Because the DTES style is always considered black and white and cheap. Cheap printing, black and white. ... I thought that it's really important that people get down and look really good and that the image is really strong and captures the community. . . . The photos capture the people of the community and show their humanity and show them in the context of the work they are doing, in this case it is the artistic practice. So we put a lot of emphasis on taking photos both during the Festival and after Festival. (transcripts, April 12, 2016)

The small group perspective contends that groups permit communities to represent themselves in symbolic terms through the collective development, appropriation, and interpretation of meanings and objects (Fine 2012). In the Festival setting, static images that carry emblematic significance are collectively developed and strategically utilized to enable audiences to see and sense a dynamic and vibrant community. For example, Figure 4 offers a perspective of the community within the lived experiences of those who live 
there. It is an image of the DTES as an alive and resilient community with talented musicians, poets, dancers, and visual artists that blur the distinction between professionals and community members to explore the affordances of collective creativity and the process in the making of the Festival.

\section{Discussion: The Festival and Local Culture Development}

According to Fine (2012, 26), a small group is of great value in explaining how meaning and order are established in "mesostructures" (Wynn 2015, 255) because of its four powerful forces of control, contestation, representation, and allocation. As we look into the Festival from the small group perspective, we particularly see these practices of representation and contestation. By this, we mean that when individuals participate in producing and performing the Festival, a meaning-making process, the Festival becomes (1) a "performative space" (Hamilton 2012) in which community residents represent themselves and community in symbolic, multiliterate productions and (2) an action space that encourages co-engagement and active resistance to stigmatized labeling. In the process, a local culture is simultaneously generated within the Festival, a cultural field, to support community identity construction.

As previously mentioned, most Festival productions feature the work of community residents and local artists, who conceive and contribute experience and meanings and then perform their artistic works at the Festival, either through spoken word and text, or through visual and multimedia arts. Meaning-making is "an ongoing process that is achieved through shared history” (Fine 2010, 356). Building on shared memories and lived experiences, Festival participants/community residents mobilize multiliterate resources to produce new constructions and representations of social realities. While participating in meaning-making, they create communal and personal identification with each other and their community at the same time. Multiliteracies approaches view this active process of working upon emergent meaning as “Designing” (New London Group 1996; Kress and Van Leeuwen 2001). And those cultural and multiliterate texts/events that are produced in the process are considered "performative spaces" (Hamilton 2012). At the Festival, community residents, taking on multiple roles "as meaning-makers, as agents, as participants, and even as active citizens" (Kalantzis and Cope 2012, 142), coengage with critical agency in the "Designing" process to represent themselves and their community in symbolic terms and to construct their sense of place and cultural identity. 
As Wynn $(2015,44)$ has shown in his study of music festivals, "festivals are the result of participants' collective action.” More than that, the fact that a wide range of multiliterate resources are entwined with artistic performances that include community residents who collaborate during the year toward the annual show highlights the fact that the HOTC Festival also facilitates co-engagement, and consequently, inclusive civic culture/community. Such a civic culture space enables local residents of diverse ethnic and cultural backgrounds to interact with each other to share knowledge and skills, feel interpersonal satisfactions, and experience a sense of hope and dignity. "It's the highlight of the entire city that we put this (the Festival) together and it's about the re-establishing and re-collecting the fire within this community,” noted Stephen, a local DTES resident and community actor, "and it gives people a sense of hope, a sense of dignity, a sense of being alive" (transcripts, August 15, 2015).

It is without a doubt that voices of self or groups are (re)shaped "by the context and strategies used to produce them" (Hamilton 2012, 76). Nonetheless, not only does the context frame texts, but the inverse also occurs. In the case of the Festival, performances/cultural texts embody values and tradition that have been embedded within the DTES community, "a particular cultural context in which real people live, work, and practice the art of community and politics, together" (Borer 2006b, 179). Meanwhile, the Festival helps (re)define place identity by (re)producing symbolic representations and images of the community for community advocacy. Collective memories, semiotic resources of visualization, and metaphorical symbols are tactically used to create a counter-discourse. In this sense, the Festival functions as a site for "unofficial protest" (Wynn 2015), on which community residents challenge the undesired identities by reshaping the community's cultural landscape.

We further bring together the small-group theory and urban culturalist perspective to theorize the group-culture-place relationships (Figure 5) and consider the Festival as a vital but neglected space for place-making, conscientization, and multiliterate meaning-making. In the active "Designing" process, a unique local culture is developed within the Festival. This group culture is created through the public display of the diversity, variety, and cultural wealth of the DTES, and performed and practiced in multimodal productions. It is also a local achievement of participants' agency developed through shared participation and co-engagement. This culture is produced, represented, and perceived through narratives/collective memories, a vibrant civic space, and symbolic and expressive images/representations. Here, the Festival operates as the arena for cultural praxis in which individuals renegotiate and redevelop community identity while attaching 
meaning and emotional value to place. In the meantime, the Festival, a cultural text itself that is deeply rooted in and nourished by the DTES/place, helps people make sense of their identity and the structures and forces that shape their experiences by positioning participants in shared memories and symbolic representations. In doing so, the Festival successfully cultivates strong ties between local communities, deepens education about the complexity and cultural wealth of the DTES, and crafts unique urban festival experiences.

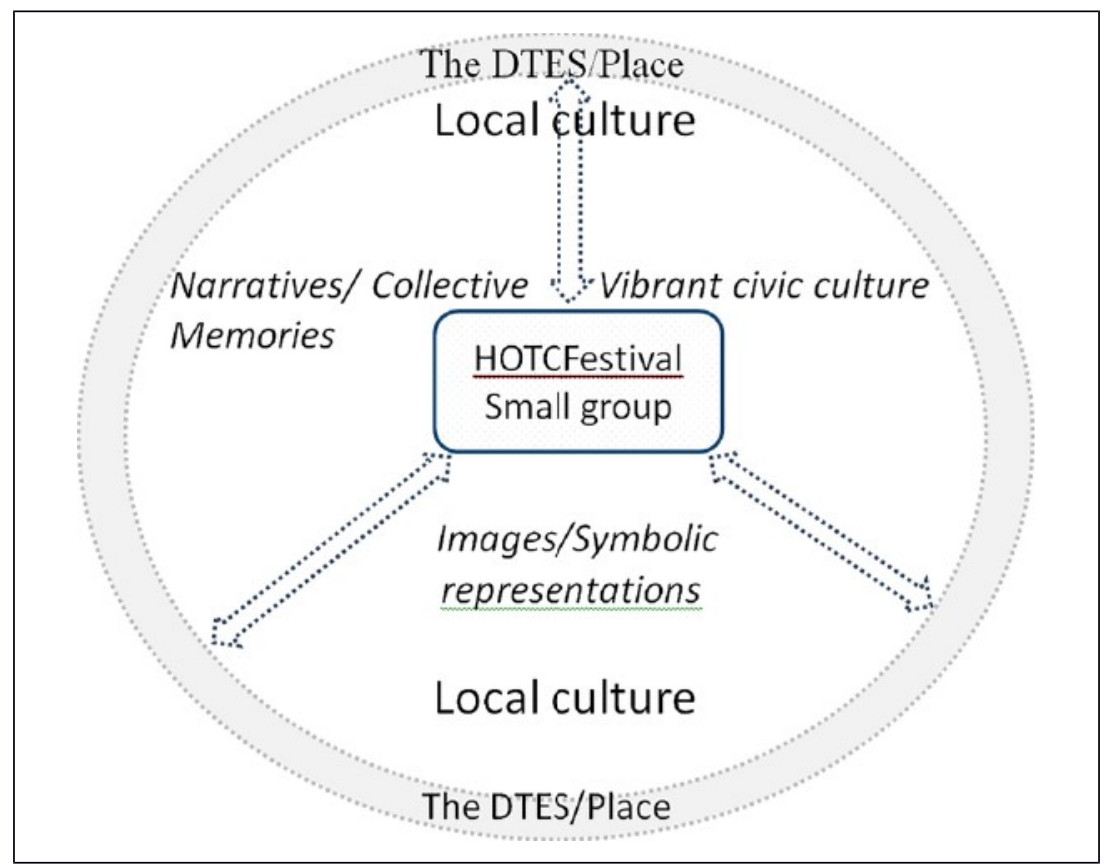

Figure 5. Group-culture-place relationships in the Festival context.

\section{Conclusion}

Drawing upon the small-group theory and urban culturalist perspective, we have explored in this ethnographic case study a community-engaged festival in Downtown Vancouver and its multiple roles in helping give voice to community residents who are otherwise discursively and politically "silenced." We conceive the Festival as a local, group context in which 
community residents and their diaspora, through shared participation and collective engagement, develop and perform local culture for identity construction and meaning/place making. We demonstrate with multiple examples how the Festival, transitory and temporally bounded as it is, has powerful influences upon local culture development and identity building. With this study, we hope to expand further discussion on community festivals as a socially meaningful means for collective action, community building, and multiliterate meaning-making in urban environments.

\section{Acknowledgment}

It is with honor and gratitude that we acknowledge that this research has been conducted on the unceded ancestral territories of the Coast Salish peoples, specifically the $\mathrm{x}^{\mathrm{w}} \mathrm{m} \partial \partial \theta \mathrm{k} ə \partial^{\mathrm{w}} \mathrm{ym}$ (Musqueam), Skwxwú7mesh (Squamish), and selílwitulh (Tsleil-Wauthuth) First Nations.

\section{Declaration of Conflicting Interests}

The author(s) declared no potential conflicts of interest with respect to the research, authorship, and/or publication of this article.

\section{Funding}

The author(s) received no financial support for the research, authorship, and/or publication of this article.

\section{Notes}

1. The term multiliteracies was created by the "New London group" (1996) and refers to the two major aspects of meaning-making: social diversity and multimodality (Kalantzis and Cope 2012). Our focus here is placed on the multimodality dimension of multiliteracies. In this article, multiliteracies and multimodal literacies are used as two interchangeable terms and both refer to the multiple modes (language, visual, spatial, and digital) of meaning-making.

2. Vancouver Moving Theatre is a professional arts organization founded in 1983 by two DTES artists/residents, Terry Hunter and Savannah Walling. It is now the lead producer of the Festival.

3. Author 1 did three years of fieldwork as part of her doctoral dissertation research. Both Author 2 and Author 3 have contributed to writing of the article.

4. Wynn $(2015,228)$ points out that the process of producing festivals depends on the "crafting of temporary cultural and entertainment-based spaces" and flexible 
programming that "can more fluidly respond to the changing needs of the city, its residents, and the audience that attends." He refers to this kind of festival culture as "liquid culture," as opposed to concrete culture.

\section{References}

Adrienne, Acallum. E-mail message to Author 1, August 11/December 1, 2016.

Against the Current: A Collaborative Cross-Cultural Performance. November 6, 2015. Performance brochure. Vancouver Moving Theater \& Downtown Eastside Heart of the City Festival.

Albers, Peggy, and Jerome C. Harste. 2007. "The Arts, New Literacies, and Multimodality.” English Education 40 (1): 6-20.

Bird, Elizabeth S. 2002. "It Makes Sense to Us: Cultural Identity in Local Legends of Place.” Journal of Contemporary Ethnography 31 (5): 519-47.

Borer, Michael Ian. 2006a. "Important Places and Their Public Faces: Understanding Fenway Park as a Public Symbol.” Journal of Popular Culture 39 (2): 205-24.

Borer, Michael Ian. 2006b. "The Location of Culture: The Urban Culturalist Perspective.” City \& Community 5 (2): 173-97.

Borer, Michael Ian. 2010. "From Collective Memory to Collective Imagination: Time, Place, and Urban Redevelopment.” Symbolic Interaction 33 (1): 96-114.

Brethour, Patrick. 2009. "Exclusive Demographic Picture." The Globe and Mail, February

http://www.theglobeandmail.com/incoming/exclusive-demographic-picture/article 4277604/ (accessed March 10, 2016).

Che, Deborah. 2008. "Sports, Music, Entertainment and the Destination Branding of Post-Fordist Detroit.” Tourism Recreation Research 33 (2): 195-206.

City of Vancouver. 2015. "City of Vancouver DTES Plan.” http://vancouver.ca/files/ cov/downtown-eastside-plan.pdf (accessed January 5, 2017).

Cope, Bill, and Mary Kalantzis. 2000. Multiliteracies: Literacy Learning and the Design of Social Futures. London: Routledge.

Delgado, Melvin. 2016. Celebrating Urban Community Life: Fairs, Festivals, Parades, and Community Practice. Buffalo: University of Toronto Press.

Derrett, Ross. 2003. "Making sense of how festivals demonstrate a community's sense of place.” Event and Management 8(1): 49-58.

Downtown Eastside Heart of the City Festival Comment Book. 2014. Vancouver: Vancouver Moving Theater.

Downtown Heart of the City Festival Program Guide. 2014. Vancouver: Vancouver Moving Theater.

Elias-Vavotsis, Sophie. 2006. "Festivals and Events-(Re)interpreting Cultural Identity.” Tourism Review 61(2): 24-29.

Fine, Gary Alan. 1979. "Small Groups and Cultural Creation: The Idioculture of Little League Baseball Teams.” American Sociological Review 44:733-45. [AQ1]

Fine, Gary Alan. 2010. "The Sociology of the Local: Action and Its Publics." Sociological Theory 28 (4): 355-76.

Fine, Gary Alan. 2012. Tiny Publics: A Theory of Group Action and Culture. New York: Russell Sage Foundation. 
Foley, Malcolm, and Gayle McPherson. 2007. “Glasgow’s Winter Festival: Can Cultural Leadership Serve the Common Good?” Managing Leisure 12 (2/3): 143-56.

Getz, Donald. 2010. “The Nature and Scope of Festival Studies.” International Journal of Event Management Research 5 (1): 1-47.

Hamilton, Mary. 2012. Literacy and the Politics of Representation. London: Routledge.

Hopper, Tristin. 2014. “Vancouver's 'Gulag': Canada's Poorest Neighbourhood Refuses to Get Better Despite \$1M a Day in Social Spending.” National Post, November

http://news.nationalpost.com/news/vancouvers-gulag-canadas-poorest-neighbourh ood-refuses-to-get-better-despite-1m-a-day-in-social-spending (accessed March 18, 2016).

Hughes, George. 1999. "Urban Revitalization: The Use of Festive Time Strategies.” Leisure Studies18 (2): 119-35.

Hull, Glynda, and Katherine Schultz. 2001. "Literacy and Learning Out of School: A Review of Theory and Research.” Review of Educational Research 71 (4): 575-611.

Jepson, Allan, and Alan Clarke. 2016. “An Introduction to Planning and Managing Communities, Festivals, and Events.” In Managing and Developing Communities, Festivals and Events, edited by A. Jepson and A. Clarke, 3-15. London, UK: Palgrave Macmillan.

Kalantzis, Mary, and Bill Cope. 2012. Literacies. Cambridge: Cambridge University Press. Kress, Gunther. 2000. “Multimodality.” In Multiliteracies: Literacy Learning and the Design of Social Futures, edited by B. Cope and M. Kalantzis, 182-202. New York: Routledge.

Kress, Gunther, and Theo Van Leeuwen. 2001. Multimodal Discourse: The Modes and Media of Contemporary Communication. London, UK: Edward Arnold.

Lather, Patti. 1986. "Issues of Validity in Openly Ideological Research: Between a Rock and a Soft Place.” Interchange 17:63-84.

McClinchey, K. 2008. "Urban Ethnic Festivals, Neighborhoods, and the Multiple Realities of Marketing Place.” Journal of Travel and Tourism Marketing 25 (3/4): 251-64.

Monti, Daniele J. 1999. The American City: A Social and Cultural History. Malden: MA: Blackwell.

Moscardo, Gianna. 2007. “Analyzing the Role of Festivals and Events in Regional Development.” Event Management 11 (1/2): 23-32.

New London Group. 1996. "A Pedagogy of Multiliteracies: Designing Social Futures.” Harvard Educational Review 66 (1): 60-92.

Pidgeon, Michelle, and Donna Cox. 2002. "Researching with Aboriginal Peoples: Practices and Principles.” Canadian Journal of Native Education 26:96-106.

Reid, Gavin. 2006. "The Politics of City Imaging: A Case Study of the MTV Europe Music Awards Edinburgh 03.” Event Management 10 (1): 35-46.

Reid, Sacha. 2007. "Identifying Social Consequences of Rural Events." Event Management 11 (1/2): 89-98.

Robinson, Natalie. 2012. "Picturing social inclusion: Photography and identity in Downtown Eastside Vancouver.” Unpublished master's dissertation, University of Birmingham. 
Sanders, Jennifer, and Peggy Albers. 2010. "Multimodal Literacies: An Introduction.” In Literacies, the Arts and Multimodality, edited by P. Albers and J. Sanders, 1-25. Urbana, IL: National Council of Teaching of English.

Smith, Janet. 2016. “Artists at Heart of the City Festival Throw Fresh Light on the Downtown Eastside." The Georgia Straight, October 19. http://www.straight.com/arts/810026/artists-heart-city-festival-throw-fresh-lig ht-downtown-eastside (accessed November 11, 2016).

Szöke, Teréz. 2015. "Investigating the Geographies of Community-Based Public Art and Gentrification in Downtown Eastside, Vancouver.” Master's dissertation, the University of Guelph.

Wynn, Jonathan R. 2015. Music/City: American Festivals and Placemaking in Austin, Nashville, and Newport. Chicago: University of Chicago Press.

Yin, Robert K. 2011. Qualitative Research from Start to Finish. New York: Guilford.

Yin, Robert K. 2014. Case Study Research: Design and Methods. Los Angeles, CA: Sage. [AQ2]

Zerubavel, Eviatar. 1996. "Social Memories: Steps to a Sociology of the Past." Qualitative Sociology 19:283-99.

\section{Author Biographies}

XXXXXX [AQ3] 